\title{
A Study on Yu Kilchun and His Network of Acquaintances (1881-1907)*
}

Masutani Yuichi**

\section{Introduction}

$\mathrm{Yu}$ Kilchun (1856-1914) has been in the spotlight from early on as a member of the Enlightenment Party who left a considerable body of written works. His major work was Sŏyu kyŏnmun (Observations on a journey to the West), which was completed in the spring of 1889 and published in April 1895. Many studies on Yu Kilchun have focused on Sŏyu kyŏnmun and the formation of his ideologies. Studies on his later years include a paper on his educational activities and Hansŏngbuminhoe (Society of Seoul residents), which has not received a lot of attention, and those that attempted to understand even his later years in light of Sŏyu kyŏnmun. However, it is now necessary to approach and examine Yu Kilchun from a new perspective. ${ }^{1}$

* This work was supported by the National Research Foundation of Korea Grant funded by the Korean Government (NRF-2014S1A5B4037006).

** 桝谷祐一, Ph.D. Candidate, Department of Korean History, Korea University

1 For the trend and problems of research on Yu Kilchun, I referred to Ch'oe Deoksu's study on the history of research on Yu Kilchun. Ch'oe Tŏksu, 2015, "Haebang hu Yu Kilchun yŏn'gu ŭi sŏnggwa wa kwaje" (Achievements and problems of the research on Yu Kilchun after the Korean liberation from the Japanese rule). Ch'oe Tŏksu p'yŏn. Kŭndae Han'guk ŭi kaehyŏk kusang kwa Yu Kilchun (Reform ideas in modern Korea and Yu Kilchun). Koryŏ Taehakkyo Ch'ulp'an Munhwawŏn. 
One of the topics that has been examined to a limited extent was his circle of friends. Studies on this topic have pointed out that Yu Kilchun studied under Pak Kyusu, Kim Okkyun, Kang Wi, O Kyŏngsŏk, and Min Yŏngik in his adolescence ${ }^{2}$ and the process of the formation of his ideology was influenced by Fukuzawa Yukichi (福澤諭吉) during his studies in Japan. $^{3}$ A former study emphasized the relationship between Yu and Edward Sylvester Morse in connection with the theory of social evolution. ${ }^{4}$ Aside from these studies, no other studies address his personal connections. Even several papers that explore his life in detail ${ }^{5}$ do not explore his acquaintances in detail other than the people mentioned above. In particular, Yu's movements after his exile in 1896 up to his return to Korea

(First published in 2013).

2 Yu Tongchun, 1987, Yu Kilchun chŏn (A biography of Yu Kilchun), Iljogak, 15-47. However, this book includes a number of uncertain narratives about Yu Kilchun's adolescence.

3 A study that provided a comparative analysis of Yu Kilchun's Soyu kyŏnmun and Fukuzawa Yukichi's Seiyo jijo (Conditions in the West) is Tsukiashi Tatsuhiko, 2009, "Chosen kaika shiso no kozo-Yu Kilchun Sŏyu kyŏnmun no bunmeiron teki rikken kunshuseiron" (The structure of enlightenment thought in Chosŏn-Yu Kilchun's theory of constitutional monarchy), Chosen kaika shiso to nashonarizu$m u$ (Enlightenment thought and nationalism in Korea). Tokyo Daigaku Shuppankai.

4 Chŏn Pokhŭi, 1996, Sahoe chinhwaron kwa kukga sasang (The theory of social evolution and national ideologies), Hanul; Hŏ Tonghyŏn, 2002, "1880 nyŏndae kaehwap'a insadŭl ŭi sahoe chinhwaron suyong yangt'ae pigyo yŏn'gu” (A comparative study of the aspects of acceptance of the theory of social evolution by the members of the Enlightenment Party). Sach'ong (The historical journal) 55.

5 Yi Kwangnin, 1991, Yu Kilchun: tach'in sahoe e tǒnjin ch'unggyŏk (Yu Kilchun: a shock through a closed society), Tonga Ilbosa; Chŏng Yonghwa, 2004, "Yu Kilchun ŭisaengae wa Han'guk kŭndaesa" (Yu Kilchun's life and the history of modern Korea), Munmyŏng ŭi chŏngch'i sasang: Yu Kilchun kwa kündae Han'guk (Political ideologies of civilization: Yu Kilchun and modern Korea), Munhakgwa Chisŏngsa; Han Ch'ŏlho, 2009, "Yu Kilchun ŭi saengae wa sasang" (Yu Kilchun's life and thoughts), Han'guk kündae kaehwap'a wa t'ongch'i kigu yŏn'gu (A study of the Enlightenment Party and the governing body in modern Korea), Sornin. 
in 1907 have not been explored much, other than a study on the Hyŏngmyŏng ilsimhoe(One mind association for revolution) incident in $1902 .^{6}$

The "Collection of new materials related to Yu Kilchun," which has been donated by Yu's descendants and are housed at the Korea University Museum, has important value as historical materials that provide opportunities for research on $\mathrm{Yu}$ Kilchun from a new perspective. ${ }^{7}$ Among the newly discovered resources, there are three address books that $\mathrm{Yu}$ Kilchun used. In addition, two volumes of journals Yu kept during his exile in Japan in 1901 were found as well. Yu's connections have not been fully explored until now, and these sources reveal the formation of Yu Kilchun's connections according to different time periods. This paper will examine and analyze newspaper articles and other sources in addition to the address books and journals to examine the type of connections $\mathrm{Yu}$ had in his lifetime. ${ }^{8}$

\section{The Nature of Newly Discovered Sources: Address Books and Journals}

Sources from the "Collection of new materials related to Yu Kilchun" that are used in this paper include address booksand journals. First, of the three address books, one is titled Chiurok (Records of close acquaintances)," and the other two are untitled. These latter address books will be referred to as "Address book 1" and "Address book 2" in this paper.

6 Yun Pyŏnghŭi, 1998, “Ilbon mangmyŏng sijŏl Yu Kilchun ŭi k’udet'a ŭmmo sagŏn" (Yu Kilchun's coup d'état conspiracy during his exile in Japan), Yu Kilchun yŏn'gu (A study on Yu Kilchun), Kukhak Charyowǒn.

7 Regarding the "Collection of new materials related to Yu Kilchun," refer to Ch'oe, "Haebang hu Yu Kilchun yŏn'gu," Kŭndae Han'guk ǔi kaehyŏk kusang, 32-33.

8 This study examines the period before Yu Kilchun's return to Korea from his exile in Japan in 1907. The period after 1907 will be explored through the analysis of the "Collection of new materials" and discussed in another paper. 
Figure 1. Chiurok, Address book1, Address book2 (from left)

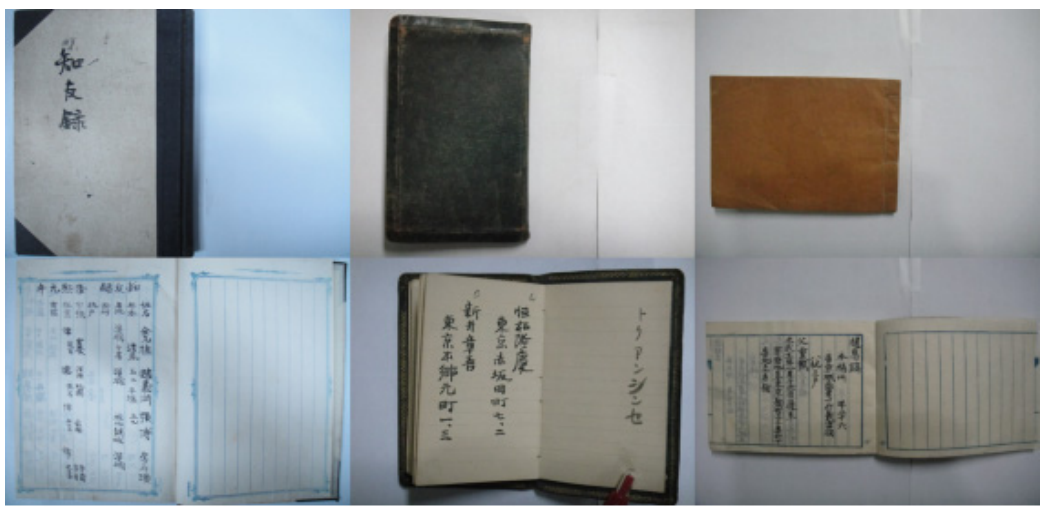

In Chiurok, there are 454 contact entries for Koreans, 161 for Japanese, and 2 others, reaching a total of 617 entries (including duplicate entries). It can be largely divided into three parts, and the third part makes up a large part of the overall address book. The first part of the address book contains a list of items, such as "name," "birth year," "address," "town and village," "neighborhood and house number," "courtesy name or pseudonym," "occupation," and "secondary address." The entries in this part include information under each of the above items. Entries in the second part list names, addresses or details about people. The third part lists names under different surnames, such as "Lee" and "Kim." The first page displays "Yunghŭi wŏnnyŏn (1907, first year in the Yunghŭi Era), but it seems that only the first part contains information from 1907. For instance, the entry on Yu Chinho (俞鎭浩) in the second part of the address book includes the information that he was "Kanggye kunsu (magistrate of Kanggye county)." However, Yu Chinho was appointed as the magistrate of Kanggye county on July 30, 1908. As for Sŏ Sangmyŏn, "magistrate of Koyang county," it was confirmed that he was appointed as the magistrate of Koyang county on May 26, 1911. ${ }^{9}$ Therefore the

9 Regarding the appointment of Yu Chinho and Sŏ Sangmyŏn as government officials, refer to An Yongsik, 1994, Han'guk haengjŏngsa yŏn'gu (A study of the his- 
contact information recorded in the second and third parts seems to reflect the situations in or after 1911.

Figure 2. Part 1 (1907), Part 2 (In or after 1911), Part 3(In or after 1911) (from left)

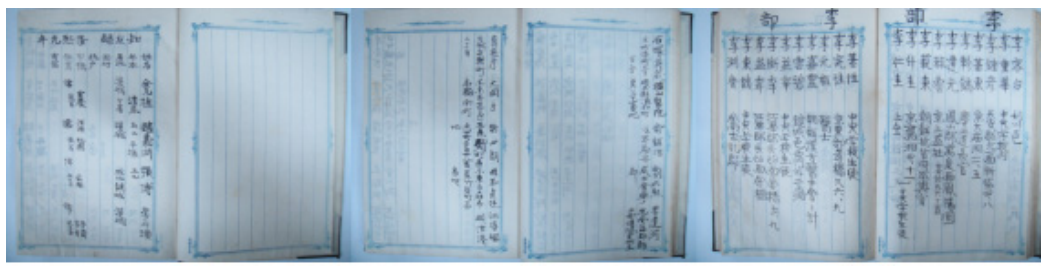

Address book 1 was a pocket book that makes distinctions between Koreans and Japanese. There are 35 entries on Koreans, 123 on Japanese, and 3 others. The entry on Tarui Tokichi (樽井藤吉) contains the record “Meiji year 40, year 59 (明治四十年五十九年)”; and the entry on Kohira Kyo (小平矯)displays the record “Meiji year 40, year 51 (明治四十年五十 一年).” This shows that the entries were made before he returned to Korea from his exile in Japan in 1907. The changes in his handwriting show that the entries have been recorded over several occasions. However, information about people he met are not recorded in the order in which he met them, which suggests that there is a possibility that he might have rerecorded the entries from another address book or wrote down information from name cards. Address book 1 lists entries with a circle (०) or a check mark $(\sqrt{ })$ over names and contains traces of reorganization.

Address book 2 contains contact information for 36 Koreans. All of them were students studying abroad in Japan, and several or all of them might be students sent from the Tonghak Order. ${ }^{10}$ The entries list the items "name," "family clan," "address in Korea," "father's name," "date of arrival in Japan," and "address in Japan" in such order. The entries in

tory of Korean administration) Vol. 1, Taeyŏng Munhwasa, 250, 338.

10 For the activities of the Tonghak Order after the Sino-Russian War, refer to Yumi Moon, 2013, Populist Collaboratiors: The Ilchinhoe and the Japanese Colonization of Korea, 1896-1910, Cornell University Press. 
this address book seem to have been for student management. These were recorded after $\mathrm{Yu}$ Kilchun was released from his exile on the Ogasawara Islands in 1906 up until his return to Korea in 1907. There are no duplicate entries between Address book 1 and Address book 2, which were recorded at around the same period. ${ }^{11}$

The entries of people and their contact information from Yu's address books can be summarized into the following categories in light of the nature of the sources:

Table1. Categories in Light of the Nature of the Sources

\begin{tabular}{c|c|c}
\hline $\begin{array}{c}\text { Names appearing in } \\
\text { address books }\end{array}$ & Relationship with Yu Kilchun & Example \\
\hline $\begin{array}{c}\text { In Address Book } 1 \\
\text { and Chiurok }\end{array}$ & $\begin{array}{c}\text { Has close ties from during the } \\
\text { exile (1906-1907) or before }\end{array}$ & $\begin{array}{c}\text { O Sech ang } \\
\text { Nakamura Tahachiro }\end{array}$ \\
\hline $\begin{array}{c}\text { In Address Book } 1 \\
\text { but not in Chiurok }\end{array}$ & $\begin{array}{c}\text { Seldom in contact after } \\
\text { returning to Korea }\end{array}$ & $\begin{array}{c}\text { Sang Ho } \\
\text { Okamoto Ryunosuke }\end{array}$ \\
\hline $\begin{array}{c}\text { Not in Address Book } \\
\text { 1 but in Chiurok }\end{array}$ & $\begin{array}{c}\text { Established or deepened ties } \\
\text { after returning to Korea }\end{array}$ & $\begin{array}{c}\text { Kim Yunsik } \\
\text { Ogaki Takeo }\end{array}$ \\
\hline
\end{tabular}

There are exceptions that cannot be sorted into the above categories. Also, the reasons for becoming estranged or becoming friends need to be examined individually. Yu's immediate family members, such as his younger brother Yu Sŏngjun (俞星濬) and his sons Yu Man'gyŏm (俞萬兼) and Yu Okkyŏm (俞億兼) are not recorded in the address books, while entries of his relatives are recorded in them. Therefore, it is possible to assume that $\mathrm{Yu}$ 's relatives whose contact information cannot be found in the address books probably were seldom in contact with $\mathrm{Yu}$.

Other sources from the "Collection of new materials on Yu Kilchun" are his journals: Haengsaek (行索) and Pukyu ilgi (北遊日記).

11 Yu Kilchun's address books, which were part of the "Collection of new materials," have been introduced to this point. This study will focus on people who have clear relevance to Yu Kilchun's activities, and further research will be conducted at another time to examine all the people who appear in Yu's address books. 
Figure 3. Haengsaek, Pukyu ilgi (Pukhaenggi, Journal from travels to the North) (from left)

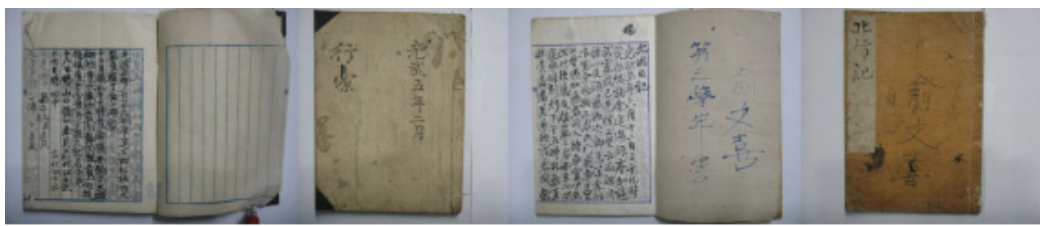

Haengsaek contains journal entries from his travels to Shizuoka and Gifu from February 16 to May 2, 1901. In the first half of the journal, Yu recorded his activities every day in a journal form, while the second half contains poems and prose as well as contact information about the people he met. On the last page was a secret code conversion chart.

The cover page of Pukyu ilgi displays the title Pukhaenggi (Records of travels to the North). It contains entries from his travels to Hokkaido from June 12 to August 3, 1901. Similar to Haengsaek, the first part of Pukyu ilgi contains his activities day by day, while the latter half contains poems, prose, and records of his visits to places. The name "Yu Munhŭi"' is written on the cover page, as well as on the back of the cover page, but this seems to have been scribbled by one of Yu Kilchun's relatives. The content of the journal indicates that $\mathrm{Yu}$ was the author of this journal.

These journals are sources that offer insight into Yu's contacts and connections during the time he planned a coup while exiled in Japan, which will be analyzed in depth in Section 4.

\section{Yu Kilchun's Studies at Keio Gijuku and the Kabo Reforms}

Yu Kilchun enrolled in Keio Gijuku on May 16, 1881, where he remained as a student until December 1882. It is well known that he studied under Fukuzawa Yukichi during this period. His address book contains entries of people from Keio Gijuku: 
Okamoto Ryunosuke (岡本柳之助, Add 1-36), Inukai Tsuyoshi (犬 養毅, Add 1-34), Kamata Eikichi (鎌田榮吉, Add 1-25), Fukuzawa Sutejiro (福澤捨次郎, Add 1-21;Chi-547), Fukuzawa Ichitaro (福澤一 太郎, Add1-26;Chi-612), Ishikawa Kanmei (石河幹明, Add 1-22; Add 1-65; Chi-258; Chi-614) ${ }^{12}$

There are more people in the address books who have studied at Keio Gijuku, but the people listed above are those who were at Keio Gijuku during the time $\mathrm{Yu}$ was studying there. Since Fukuzawa Yukichi passed away in 1901, his contact information is not listed in the address books. Fukuzawa Yukichi's sons, Ichitaro and Sutejiro, studied with Yu at Fukuzawa's house, and are presumed to have been friends with $\mathrm{Yu}$. Ichitaro and Sutejiro left for the United States to pursue their studies in June 1883, two months before Yu himself left for the United States. ${ }^{13}$ Yu stopped by Japan on his way to the United States in August 1883 and wrote a letter to Fukuzawa Ichitaro and Sutejiro, informing them of his trip to the United States from Japan when he stopped by on his way to the United States. ${ }^{14}$ Yu Kilchun studied under Morse, an American zoologist, and it is speculated that Fukuzawa Yukichi recommended Yu to Morse. The following letter shows Yu's relationship with Fukuzawa Sutejiro:

12 Entries in three address books will be indicated by the title of the address bookChiurok, Chusorok 1, and Chusorok 2 will be abbreviated as "Chi, " 'Add 1," and "Add 2"-followed by the number in the order the entry was found in the relevant address book. For example, "Add 1-36" is the name found in the 36th entry in $A d$ dress book 1 . The names listed in the address books are noted in this format because it is possible that the order in which the entries were recorded could have significance.

13 "Hochu (koto) Ichitaro to Sutejiro no ryugaku," (Supplementary note: Ichitaro's and Sutejiro's study abroad), Fukuzawa Yukichi shokanshu (Collection of Fukuzawa Yukichi's letters) Vol. 4, 2001, 352.

14 "Fukuzawa Ichitaro, Fukuzawa Sutejiro: August 17, Meiji 16 (1883)," Fukuzawa Yukichi shokanshu (Collection of Fukuzawa Yukichi's letters) Vol. 3, 324-325. 
As for Sutejiro, when he visited your house to enroll in the school in Boston, he received your kind help every time, and I am very grateful. I heard that he visited you almost every day while his stay at Salem, and I was worried that he has pestered you too much...You are also providing room and board for Yu Kilchun, a Korean student. He stayed with me for a long period in Japan last year. Although he does not speak English, he knows of the western civilization. I am very happy to know that he is learning English thanks to you and is advancing in his studies... ${ }^{15}$

Fukuzawa seems to have entrusted Sutejiro to Morse and introduced $\mathrm{Yu}$ Kilchun to Morse in the same way. Yu was not completely alone when he studied in Salem, as he had been accompanied by a friend, Sutejiro.

Not many entries of people from Keio Gijuku are found in Yu's address books, but $\mathrm{Yu}$ had ties to a number of people from Keio Gijuku. In an interview in 1894, a reporter from Yomiuri Shimbun asked Yu Kilchun, "Since you studied at Keio Gijuku, you must know a lot of elite intellectuals, don't you?" Yu Kilchun answered, "I was only a student, so I am not acquainted with ministerial level officials. But I am friends with quite a number of people, including my teacher Fukuzawa Yukichi, Obata Tokujiro (小幡篤次郎, 1842-1905), and members of the national Diet, such as Ozaki Yukio (尾崎行雄, 1858-1954), Inukai Tsuyoshi (犬養毅, 18551932), and Inoue Kakugoro (井上角五郎, 1860-1938)." ${ }^{16}$ All the people $\mathrm{Yu}$ mentioned in this interview were from Keio Gijuku, and all of them except for Fukuzawa and Obata were similar in age to Yu Kilchun, which shows that $\mathrm{Yu}$ had befriended Japanese students at Keio Gijuku. His

15 “E. S. Mosu, August 13, Meiji 17," (E. S. Morse, August 13, Meiji 17), Fukuzawa Yukichi shokanshu (Collection of Fukuzawa Yukichi's letters) Vol. 4, 171. Original text in Japanese.

16 "Yu Kilchun-shi wo toburau" (Visit to Mr. Yu Kilchun), Yomiuri shimbun, October $31,1894,2$. 
friendship with Ishikawa Kanmei (石河幹明) is also speculated to have been formed around this time and continued for a long time.

During the Kabo Reform period (August 1894-February 1896), Yu attended reunions of Japanese Keio Gijuku alumni in Korea. The first school reunion ${ }^{17}$ was held on May 12, 1895, at Noinjŏng in Namsan. Over ten people were in attendance, of which Japanese nationals includedKoganei Kenzaburo (小金井權三郎), Takami Hisashi (高見穒), Hozumi Torakuro (穗積寅九郎), Enami Tetsuo (江南哲夫), Sasaki Tadashi(佐佐木 正), and a reporter from Jiji Shinpo (時事新報, Times) who was presumed to be Ohara Shinkichi (小原信吉); Korean nationals were Yu Kilchun, Kim Insik, Ŏm Chuhong, Sin Chaeyŏng (Chi-232), Pak Yŏngu, An Yŏngsu, Cho Pyŏnggyo (Chi-439), Yu Sŏngchun, Paek Ch’ŏlyong, and Yi Ch'angryŏl. People who had been invited but were unable to attend included Kim Iksŭng, Hyŏn Yŏngun, Chŏng Hun'gyo, and Chŏng Ran'gyo (Add 1-143; Chi-11; Chi-127; Chi-399). Not all of the Koreans who attended the reunion were people who attended Keio Gijuku but were acquaintances of those who attended the school. The report stated that $\mathrm{Yu}$ Kilchun took charge of cleaning up the space and preparing for the reunion, which shows that he was mainly involved with the preparation of the reunion. The second reunion (held on September 1, 1895) ${ }^{18}$ was attended by $\mathrm{Yu}$ Kilchun, Yun Ch'iho, Hyŏn Yŏngun, Yun Ch'io (Chi-22; Chi-449), Kamata Eikichi (鐮田榮吉), Hozumi Torakuro (穗積寅 九郎), Nishikawa Tsutetsu(西川通徹), Ogawa Shinkichi, among others. According to the article that reported the reunion, a total of 22 Koreans and 13 Japanese nationals attended the reunion. The third reunion (held on January 19,1896$)^{19}$ was held as a party in celebration of the New

17 "Keizo tokuho May 13" (Special news from Kyŏngsŏng (Seoul) May 13), Jiji Shinpo, May 26, 1895, 3.

18 "Keizo tokuho Sep. 1" (Special news from Kyŏngsŏng (Seoul) Sep. 1), Jiji Shinpo, September 12, 1895, 2.

19 "Keizo tokuho Jan. 20" (Special news from Kyŏngsŏng (Seoul) Jan. 20), Jiji Shinpo, Jauary $31,1896,3$. 
Year at P'asŏnggwan. Korean attendees were Paek Ch'ŏlyong (白喆鏞), Pak Yŏnghun (朴永勳), Ko Yŏnghŭi (高永喜), Hyŏn Yŏngun(玄暎運), Chŏng Chongchin (鄭鍾振), Kim Yŏngch'an (金永燦, Chi-26), Kim Insik (金仁植), Yu Kilchun (俞吉濬), Sin Chaeyŏng (申載永), and Sŏ Chaep'il (徐載弱); Japanese attendees included Nishikawa Tsutetsu (西川通徹), Takami Hisashi, Uchida Sadatsuchi (内田定槌), Kusumoto Taketoshi (楠 本武俊), Yamazaki Masahide (山崎正秀), Mariko Hachigoro (閒利子八五 郎), Matsumi Tokubun (松見得聞), Koyama Mitsutoshi (小山光利), Mizushima Setsujiro (水嶋節次郎).

Graduates of Keio Gijuku socialized through these reunions, which means Yu Kilchun's network of acquaintances from school had been formed. Takami Hisashi, Ogawa Shinkichi, Mariko Hachigoro (reporters fromJiji Shinpo), Nishikawa Tsutetsu (Asahi Shimbun reporter), and Yamazaki Masahide (Tokyo Nichinichi Shimbun reporter) gained opportunities to exchange inside information with Korean government officials at these reunions. It is likely that Yu Kilchun also tried to use his ties and connections with the people he met at reunions for government administration.

Because existing address books are records from around 1906, Korean nationals who are listed in Yu Kilchun's address books are limited to people who were in exile with Yu or people Yu met after he returned to Korea. As a result, it is difficult to determine Yu's acquaintances during the Kabo Reform period from his address books. Studies have considered Yu to be part of Kim Koengchip (Kim Hongchip) and his circle in 1896, ${ }^{20}$ and he is considered to have befriended people who belonged to this cir-

20 Wang Hyŏnjong, 2003, Han'guk kŭndae kukga ŭi hyŏngsŏng kwa Kabo kaehyŏk (The formation of modern nation of Korea and the Kabo Reforms), Yŏksa Pip'yŏngsa, 165, footnote 86. Also, according to Wang Hyŏnjong's own categorization, Yu Kilchun is considered "Kaehyŏk kwallyo (B)" (Reformist officials, B), along with Cho Hŭiyŏn, Kwŏn Yŏngchin, Yi Yunyong, Yi Wanyong, Kim Kachin, Kim Haku, Chang Pak, and Yu Senam (Wang, Han'guk kŭndae kukga, 167, Table 11). "Kaehyŏk kwallyo (B)" refers to a list of people who are considered as members of the "Japanese" or "Pro-Japanese" faction. 
cle, including Kim Koengchip, Ŏ Yunchung, Kim Yunsik, Cho Hŭiyŏn, Kwŏn Yŏngchin, Chang Pak, Yu Senam, Yi Tuho, Hwang Ch'ŏl, Cho Kŭmŭng, Hyŏn Ch'ae, Pak Sehwan, Chŏng Mancho, and Kim Ch'unhŭi. In addition, from his activities in the Korean Institute (Chosen Kyokai/Chosŏn Hyŏphoe), Yu seems to have had a broad circle of acquaintances regardless of political differences.

On June 23, 1895, the Korean Institute, an organization to promote good relations between Korea and Japan, was established. ${ }^{21}$ Yu Kilchun's participation in this organization was confirmed, as Jiji Shinpo reported the establishment of this organization in detail. ${ }^{22}$ According to the article, the Korean Institute was created with Enami Tetsuo and Kim Insik as founding representatives. They were members of the Keio Gijuku reunion and attended the same school as $\mathrm{Yu}$ Kilchun. The inaugural assembly held at Nambyŏlgung (detached palace) was attended by 240 people. The members of the board were selected through Pak Yŏnghyo's recommendations, and the list of their names is as follows:

Vice president: Kim Yunsik (金允植)

Board members: Yu Kilchun (俞吉濬), Yun Ch'iho (尹致昊), An Kyŏngsu (安駧壽), Kwŏn Chaehyŏng (權在衡), Cho Chungŭng (趙重 應), Yi Yunyong (李允用), Yi Ch'aeyŏn (李采淵), U Pŏmsŏn (禹範 善), Hwang Ch’ŏl (黃鐵), Yŏm Chungmo (廉仲模), Chŏng Pyŏngha (鄭秉夏), Kim Kachin (金嘉鎭), Sugimura Fukashi (杉村濬), Uchida Sadatsuchi (内田定槌), Okamoto Ryunosuke (岡本柳之助), Ishizuka Eizo (石塚英藏), Tsuneya Seifuku (恆屋盛服), Hozumi Torakuro (穗 積寅九郎), Kunimoto Shigeaki (國友重章), Enami Tetsuo (江南哲夫)

Secretaries: Kim Insik (金仁植), Hyŏn Yŏngun (玄暎運), Aoyama

21 Concerning the Korean Institute, refer to Yu Yŏngik, 1990, Kabo kyŏngjang yŏn'gu (A study on the Kabo Reforms), Iljogak, 206; Wang, Han'guk kŭndae kukga, 168-169.

22 "Keizo tokuho June 23" (Special news from Kyŏngsŏng (Seoul) June 23), Jiji Shinpo, July 5, 1895, 3. 


\section{Kokei (靑山好惠)}

The president was not elected on that day. ${ }^{23}$ Other than those listed above, Sin Ŭnghŭi, Yi Kyuwan, Kuroda Takuma (黑田太久馬), and Ogawa Minoru (小川實) attended the assembly. However, these four people and Pak Yŏnghyo were excluded from the association prior to July 27, $1895 .^{24}$ A close examination of the attendees show that many reformist officials participated in the assembly, including Kim Koengchip's faction but also Pak Yŏnghyo's faction (Pak Yŏnghyo and Yi Kyuwan), the "English" faction (Yun Ch'iho, Yi Ch'aeyŏng, and Yi Yunyong). ${ }^{25}$

The first speaker at this assembly was Yun Ch'iho. When Yamada Inotaro (山田猪太郎), as a representative of the Japanese Oriental Society (Toho kyokai), proposed solidarity between the Japanese Oriental Society and the Korean Association, Yu Kilchun responded positively. The Korean Association took off with great strides, but its activities were stalled due to Pak Yŏnghyo leaving on an exile after he was charged with treason on July 6, and the assassination of Empress Myŏngsŏng.

Among the confirmed members of the Korean Association, the following people appear in Yu Kilchun's address books:

Pak Yŏnghyo (Add 1-133), Kim Yunsik (Chi-1, Chi-374), Yun Ch'iho (Chi-21), Cho Chungŭng (Chi-13, Chi-443, Add 1-131), Sin Ǔnghŭi (Chi-10, Chi-492, Add 1-127), Yi Kyuwan (Chi-338, Add 1144), Okamoto Ryunosuke (岡本柳之助, Add 1-36), Ishizuka Eizo (石塚英藏, Add 1-55; Chi-85; Chi-550), Tsuneya Seifuku (恆屋盛服, Add 1-32)

23 Kim Yunsik, Sokŭmch'ongsa (Sequel to the history of my days) Vol. 1, Kuksa Py’ŏnch'an Wiwŏnhoe, lunar calendar, leap month, May 1, 1895, 368.

24 "Keizo tokuho July 27" (Special news from Kyŏngsŏng (Seoul) July 27), Jiji Shinpo, August 7, 1895, 2.

25 Regarding the categorization of factions, refer to Wang, Han'guk kŭndae kukga, 167, Table 11. 
Among the people who participated in the Korean Assembly, there were people who had been involved in the assassination of Empress Myŏngsŏng, such as Sugimura Fukashi (杉村濬), Okamoto Ryunosuke, and Kunimoto Shigeaki (國友重章). In Yu's address books, Miura Goro (三浦梧樓, Add 1-30) and Shiba Shiro (柴四朗, Add 1-9; Chi-566) are also noted as having been involved in the assassination of Empress Myŏngsŏng.

When Emperor Kojong took refuge at the Russian legation, Yu Kilchun was immediately dismissed from his post, and an order was issued for his arrest on the charge of treason. Yu was arrested by Korean policemen in front of Kwanghwamun, but was then rescued by two Japanese employees of the Gazette Bureau (Kwanboguk). ${ }^{26}$ As no Japanese officials had taken part in or had the time to take part in rescuing Yu Kilchun, $\mathrm{Yu}$ had been unexpectedly rescued by Japanese civilians who had no knowledge of his arrest. Yu and others hid in the Japanese legation for half a day and escaped to a store owned by a Japanese merchant. ${ }^{27}$ He stayed there to observe the development of the situation, and, eventually giving up on staying in Korea, arrived in Hiroshima on April 21, $1896,{ }^{28}$ to seek political asylum.

26 Nippon Gaiko Bunsho (Documents of Japanese foreign policy) 29, February 13, 1896, "353 Chosen kunidai kunshu narabini seishigo rokoku koshikan ni jugyo tenmatsu hokoku no ken" (353 The report on the incident of the Korean king and the crown prince's refuge to the Russian legation), 684; Ito Hirobumi kankei monjo (Documents related to Ito History) 6, February 11, 1896, "Letter from Takehisa Katsuzo." In his report, Takehisa Katsuzo wrote that Japanese soldiers saved Yu Kilchun.

27 "Letter sent from Mutsu Munemitsu on February 28, 1896," Ito Hirobumi kankei monjo (Documents related to Ito History) Vol. 7, 401.

28 "Telegram: Hiroshima, April 21, afternoon, special issue," Jiji Shinpo, April 22, 1896,2 . 


\section{Yu Kilchun's Plans for a Coup d'état During Exile}

The Hyŏngmyŏng Ilsimhoe (One mind association for revolution) incident was an attempted coup d'état led by Yu Kilchun. ${ }^{29}$ As discovered in research by Yun Pyŏnghŭi, Japanese nationals also took part in this incident. People who were confirmed to have been involved in this incident are as follows:

Katono Ritsu (上遠野栗, Add 1-23; Chi-114; Chi-572), Fukagawa Junichi (深川淳一, Chi-602); Yokoi Tokuichi (橫井德一, Add 1-115)

Previous studies have pointed out that Kondo Kenkichi (近藤賢吉) and Morinaga Shinzo (守永新三) also took part in the incident. However, Inchŏnnaesŏ ${ }^{30}$ which contains information regarding the planning of the coup, reveals that there were several hundred Japanese nationals who were devoted to the incident. This suggests that Yu had quite a lot of connections and acquaintances during this time. Address book 1 also contains records of information on people who are considered to have partaken in the planning of the coup. For a closer examination of this incident, this study will now analyze Yu Kilchun's journals-Haengsaek (From February 16 to May 2, 1901) and Pukyu ilgi (Titled Pukhaenggi on the cover page, from June 12 to August 3, 1901). ${ }^{31}$

First, an entry that begins on February 16, 1901, states that Yu went to Mishima, Shizuoka Prefecture, by train the next day on February 17. On February 23, he went to the city of Shizuoka, where he remained for a while, until he went to Kumo Village in Gifu on March 21. Then Yu traveled to Ichinomiya in Nakajima, Aichi, on March 27, and moved to Tsu-

29 Regarding a summary of the Hyŏngmyŏng ilsimhoe incident, refer to Yun, 1998, "Ilbon mangmyŏng sijŏl," Yu Kilchun yŏn'gu, Kukhak Charyowŏn.

30 Yu Kilchun chŏnsŏ 4, 261-263.

31 Yu Kilchun's activities from February to August 1901, explored hereafter, have been derived from Haengsaek and Pukyu ilgi. 
shima on April 9, before returning to Ichinomiya on April 20. The next day, on April 21, Yun went to Osaka and then to Hamamatsu on April 29. The last date mentioned in Haengsaek is May 2, but other sources have confirmed that Yu went to Tokyo at 9:23 on May $4 .{ }^{32}$ During his travels, Yu met the following people: ${ }^{33}$

In the latter pages of Haengsaek, Yu Kilchun recorded information about people he met. The names mentioned in those pages are listed as follows:

Manabe Makitaro (眞鍋槇太郎), Sawayama Koichiro (澤山好一郎), Ninomiya Yoshima (二宮義嗎), Suzuki Yoshitaro (鈴木義太郎), Yokoi Jinshiro (横井甚四郎), Nakamura Juhei (中村重平), Uchida*taro (内田太郎), Shimada Yoshikado (島田義廉), Naito Masakari (内藤銊)，Tsuchikawa Eitaro (土川榮太郎), Shinohara Jukan (篠原重瓘), Abe Yoshihito (阿部義人), Yamashita Takashi (山 下隆), Fukagawa Yoshihichi (深川義七), Hisamatsu Shin (久松信), Nakamura Toraichi (中村寅一), Hayashi Myojiro (林妙治郎), Oniwa Hirataro (大庭平太郎), Fujita Chomin (藤田長民), Terada Shintaro (寺田信太郎), Shimamoto (島本, forgot first name), Miura (三浦, forgot first name), Yamaguchi Yoichi (山口餘一), Watanabe Jutaro (渡 邊壽太郎)

The underlined names have not appeared in the text of the journal. This means that $\mathrm{Yu}$ encountered a considerable number of people who do not appear in journal entries.

32 Kuksa Py'ŏnch'an Wiwŏnhoe, ed., Yosich'al Han'gukin kŏdong (Activities of people under surveillance) 2, May 4, 1901, "Yu Kilchun ŭi tongjŏng pogo" (Report on Yu Kilchun's activities), 390.The Japanese authorities thoroughly investigated and followed Yu Kilchun's activities up until this time, as can be seen in Yosich'al Han'gukin kŏdong. Yosich'al Han'gukin kŏdong (Activities of people under surveillance) $2,177,383-384$, and 387.

33 The sources are written in cursive, it is difficult to decipher the handwriting. The accuracy of several names is questionable. 
Table 2. The People Yu Met During His Travels ${ }^{34}$

\begin{tabular}{|c|c|c|c|}
\hline Name & Notes & Name & Notes \\
\hline $\begin{array}{l}\text { Kim Ŭngwŏn } \\
\text { (金應元, Chi-347) }\end{array}$ & $\begin{array}{l}\text { Feb.16- May4 } \\
\text { Traveled with Yu } \\
\text { Kilchun }\end{array}$ & $\begin{array}{l}\text { Yu Hyŏngno } \\
(\text { 柳赫魯, (Add 1- } \\
\text { 146; Chi-121) }\end{array}$ & Feb.17 Meal \\
\hline $\begin{array}{l}\text { Watanabe Jutaro } \\
\text { (渡邊壽太郎) }\end{array}$ & Feb.17 Visitor & $\begin{array}{l}\text { Yamaguchi Yoichi } \\
\text { (山口餘一) }\end{array}$ & $\begin{array}{l}\text { Feb.18 Former } \\
\text { member of the } \\
\text { Diet, visitor }\end{array}$ \\
\hline Tanaka (田中) & $\begin{array}{l}\text { Feb. } 18 \text { Former } \\
\text { member of the } \\
\text { Diet, visitor }\end{array}$ & Shimamoto (島本) & Feb.18 Visitor \\
\hline Miura (三浦) & Feb.18 Visitor & $\begin{array}{l}\text { Terada Hokotaro } \\
\text { (寺田彦太郎, Add } \\
1-40)\end{array}$ & $\begin{array}{l}\text { Feb. } 24 \text { Visitor } \\
\text { Mar.5 Food }\end{array}$ \\
\hline $\begin{array}{l}\text { Fujita Chomin } \\
\text { (藤田長民) }\end{array}$ & $\begin{array}{l}\text { Feb. } 25 \text { Captain, } \\
\text { food }\end{array}$ & $\begin{array}{l}\text { Oniwa Hirataro } \\
\text { (大庭平太郎, Add } \\
1-39 \text { ) }\end{array}$ & $\begin{array}{l}\text { Feb.25 Chivalrous, } \\
\text { food }\end{array}$ \\
\hline $\begin{array}{l}\text { Suzuki Yoshitaro } \\
\text { (鈴木義太郎) }\end{array}$ & Feb.25 Visitor & $\begin{array}{l}\text { Nakamura } \\
\text { Toraichi } \\
\text { (中村寅一, or } \\
\text { Toraichiro } \\
\text { (寅一郎)) }\end{array}$ & $\begin{array}{l}\text { Mar.3 Visitor } \\
\text { Apr.29 Visitor } \\
\text { Apr.30 Yu stayed } \\
\text { at his house }\end{array}$ \\
\hline $\begin{array}{l}\text { Terada Jusaku } \\
\text { (寺田壽作) }\end{array}$ & Mar.6 Visitor & $\begin{array}{l}\text { Matsui Yoshiyuki } \\
\text { (松井義之) }\end{array}$ & 3.8 Visitor \\
\hline $\begin{array}{l}\text { Fukagawa Yo- } \\
\text { shihichi (深川義七) }\end{array}$ & $\begin{array}{l}\text { Mar. } 21 \text { Yu stayed } \\
\text { at his house }\end{array}$ & Kajiwara (梶原) & $\begin{array}{l}3.23 \text { Police chief, } \\
\text { visitor }\end{array}$ \\
\hline *hara (原) & Mar.23 Visitor & $\begin{array}{l}\text { Tsuchikawa Eitaro } \\
\text { (土川榮太郎) }\end{array}$ & 4.3 Had a meal \\
\hline $\begin{array}{l}\text { Manabe Makitaro } \\
\text { (眞鍋梖太郎) }\end{array}$ & Apr.9 Visitor & $\begin{array}{l}\text { Yamashita Takashi } \\
\text { (山下隆) }\end{array}$ & 4.12 Visitor \\
\hline Tamura (田村) & Apr. 15 Visitor & $\begin{array}{l}\text { Kiwŏn (杞園, Add } \\
\text { 1-147) }\end{array}$ & $\begin{array}{l}\text { 4.21 Came to meet } \\
\mathrm{Yu}\end{array}$ \\
\hline
\end{tabular}


According to Pukyu ilgi, on June 12, Yu Kilchun bought a train ticket at Ueno Station and went to Aomori City on a night train. He was accompanied by Kato Takeie (加藤武家), Kato Takeotsu (加藤武乙), Fukagawa Junichi, Sudo Genjiro (須藤源次郎), and Sato Tadashi (佐藤正). At 5:30 pm on June 13, they arrived in Aomori City, boarded the ship HyogoMaru at midnight, and arrived in Hakodate at 8:30 am on June 14. There, $\mathrm{Yu}$ and his party were joined by Kim Ǔngwŏn. They all went to Sapporo on June 16 and stayed at Yamamoto's house. On June 19, Yu attended Keio Gijuku reunion and stayed at Kim Ǔngwŏn's house. He traveled to Esashi on July 9 and then to Bessho Village in Otaru on July 27. The last entry in Pukyu ilgi was written on August 3, 1901, when Yu was staying at Otaru. The people Yu met in his travels during this period are as follows:

Table 3. The People Yu Met in His travels ${ }^{35}$

\begin{tabular}{l|l|l|l}
\hline \multicolumn{1}{c|}{ Name } & \multicolumn{1}{c|}{ Notes } & \multicolumn{1}{c}{ Name } & \multicolumn{1}{c}{ Notes } \\
\hline $\begin{array}{l}\text { Kato } \\
\text { Takeie(加藤武家) }\end{array}$ & $\begin{array}{l}\text { Jun.12 - Aug.3 } \\
\text { Presumed to have } \\
\text { accompanied Yu } \\
\text { Kilchun }\end{array}$ & $\begin{array}{l}\text { Kato Takeotsu } \\
\text { (加藤武乙) }\end{array}$ & $\begin{array}{l}\text { Jun. 12 - Aug. 3 } \\
\text { Presumed to have } \\
\text { accompanied Yu } \\
\text { Kilchun }\end{array}$ \\
\hline $\begin{array}{l}\text { Fukagawa Junichi } \\
\text { (深川淳一, Chi-602) }\end{array}$ & $\begin{array}{l}\text { Jun. 12 - Aug. 3 } \\
\text { Presumed to have } \\
\text { accompanied Yu } \\
\text { Kilchun }\end{array}$ & $\begin{array}{l}\text { Sudo Genjiro } \\
\text { (須藤源次郎, Add } \\
1-19)\end{array}$ & $\begin{array}{l}\text { Jun. 12 - Aug. 3 } \\
\text { Presumed to have } \\
\text { accompanied Yu } \\
\text { Kilchun }\end{array}$ \\
\hline $\begin{array}{l}\text { *Sato Tadashi } \\
\text { (佐藤正, Add 1-33) }\end{array}$ & $\begin{array}{l}\text { June 12 - Aug. 3 } \\
\text { Presumed to have } \\
\text { accompanied Yu } \\
\text { Kilchun }\end{array}$ & $\begin{array}{l}\text { June 14 Yu called } \\
\text { on the phone, } \\
\text { stayed at his house } \\
\text { June16 Yu fol- } \\
\text { lowed him to Sap- } \\
\text { poro and stayed } \\
\text { with him }\end{array}$ \\
\hline $\begin{array}{l}\text { Kikumoto Naojiro } \\
\text { (菊本直次郎) }\end{array}$ & $\begin{array}{l}\text { June 14 Bank clerk. } \\
\text { Invited to interview } \\
\text { June 16 Visitor }\end{array}$ & $\begin{array}{l}\text { Kim Ungw金應元, Chi-347) } \\
\text { June 14 - Aug. 3 } \\
\text { Presumed to have } \\
\text { accompanied Yu }\end{array}$ \\
\hline
\end{tabular}

35 Pukyu ilgi. Asterisk (*) denotes people whose surnames were only recorded in the journal, and therefore full names have been deduced from address books 


\begin{tabular}{|c|c|c|c|}
\hline & & & Kilchun \\
\hline $\begin{array}{l}\text { Ueda Ichitaro } \\
\text { (植田一太郎) }\end{array}$ & June 17 Food & $\begin{array}{l}\text { *Izaka Shinkan } \\
\text { (井坂眞幹, Add 1- } \\
18 \text { ) }\end{array}$ & July 3 Met \\
\hline $\begin{array}{l}* \text { Matsumae Jo } \\
\text { (松前讓, Add 1-17) }\end{array}$ & \begin{tabular}{|l} 
July 9 Yu visited, \\
food \\
July 10 Food \\
July 11 Food \\
July 12 Food \\
July 15 Food \\
July 29 Food
\end{tabular} & $\begin{array}{l}\text { Imaizumi } \\
\text { Katsutaro } \\
\text { (今泉勝太郎) }\end{array}$ & $\begin{array}{l}\text { July } 9 \text { Meal } \\
\text { July } 11 \text { Meal } \\
\text { July } 15 \text { Meal } \\
\text { July } 17 \text { Meal }\end{array}$ \\
\hline $\begin{array}{l}\text { Asai Seikan } \\
\text { (淺井淸規, Add 1- } \\
\text { 42; Chi-175; Chi- } \\
\text { 538) }\end{array}$ & $\begin{array}{l}\text { July } 9 \text { Food } \\
\text { July } 10 \text { Food } \\
\text { July } 15 \text { Food }\end{array}$ & $\begin{array}{l}\text { Tazawa Kenzo } \\
\text { (田澤健藏) }\end{array}$ & July 9 Meal \\
\hline $\begin{array}{l}\text { Sawada Genko } \\
\text { (澤田玄弘) }\end{array}$ & July 9 Food & $\begin{array}{l}\text { Nozaki Harasa- } \\
\text { buro (野崎原三郎) }\end{array}$ & July 9 Meal \\
\hline $\begin{array}{l}\text { Sumitani Shohei } \\
\text { (住谷劣平) }\end{array}$ & July 9 Food & Sekikawa (關川) & July 11 Meal \\
\hline $\begin{array}{l}\text { *Nagataki Matsuta- } \\
\text { ro (永瀧松太郎, Add } \\
1-41 ; \text { Chi-613) }\end{array}$ & $\begin{array}{l}\text { July } 12 \text { Food } \\
\text { July } 18 \text { Visitor } \\
\text { July } 29 \text { Food }\end{array}$ & $\begin{array}{l}\text { Horita Kinpei } \\
\text { (堀田均平) }\end{array}$ & $\begin{array}{l}\text { July } 15 \mathrm{Yu} \text { stayed } \\
\text { at his house }\end{array}$ \\
\hline Suwa (諏訪) & $\begin{array}{l}\text { July } 15 \text { Food } \\
\text { July } 17 \text { Food }\end{array}$ & Oshima (大島) & July 18 Visitor \\
\hline $\begin{array}{l}\text { Cho Hŭimun } \\
\text { (趙羲聞, Add 1-140) }\end{array}$ & $\begin{array}{l}\text { July } 27 \text { Visited } \\
\text { from Osaka }\end{array}$ & & \\
\hline
\end{tabular}

During his stay in Hokkaido, Yu received letters from Izaka and Omura on June 23, from Sang Ho on June 24, and from Cho Chungŭng on July 27. Cho Hŭimun came from Osaka to visit Yu on July 30 and found accommodations at the official residence of the Seventh Field Force. Entries from July 30 and July 31 contain secret codes, "Oigudutaguno (오이구두 타구노)" and "Nikkachikkoaryŏ (나까치꼬아려)" respectively. After the travels recorded in Pukyu ilgi, information on Yu can be found in Inchŏnnaesŏ, which reveals seditious schemes in statements such as "Thank goodness you found like-minded people among military officers for this plan... (August 1901)" and "You have recruited about 200 Japanese peo- 
ple for this plan... (October 1901)."

In other words, Yu Kilchun traveled throughout Japan from February to August in 1901 to prepare for a coup d'état in Korea, and several people Yu met during his travels in Japan were actually involved in the coup, one major participant of which was Fukagawa Junichi (深川淳一). Yu visited Gifu since it was Fukagawa's home, ${ }^{36}$ and it is speculated that Yu visited Hokkaido because Fukagawa's sister, who married Yamamoto, was living in Hokkaido. ${ }^{37}$ In Address book 1, there are names of people who were recorded as residents of Otaru, Hokkaido. These include Soeda Hitsu (添 田怩, Add 1-44) and Nakatani Ukichi (中谷宇吉, Add 1-45), which sug-

Figure 4. The Travle Route and Staying Period of Yu Kiljun

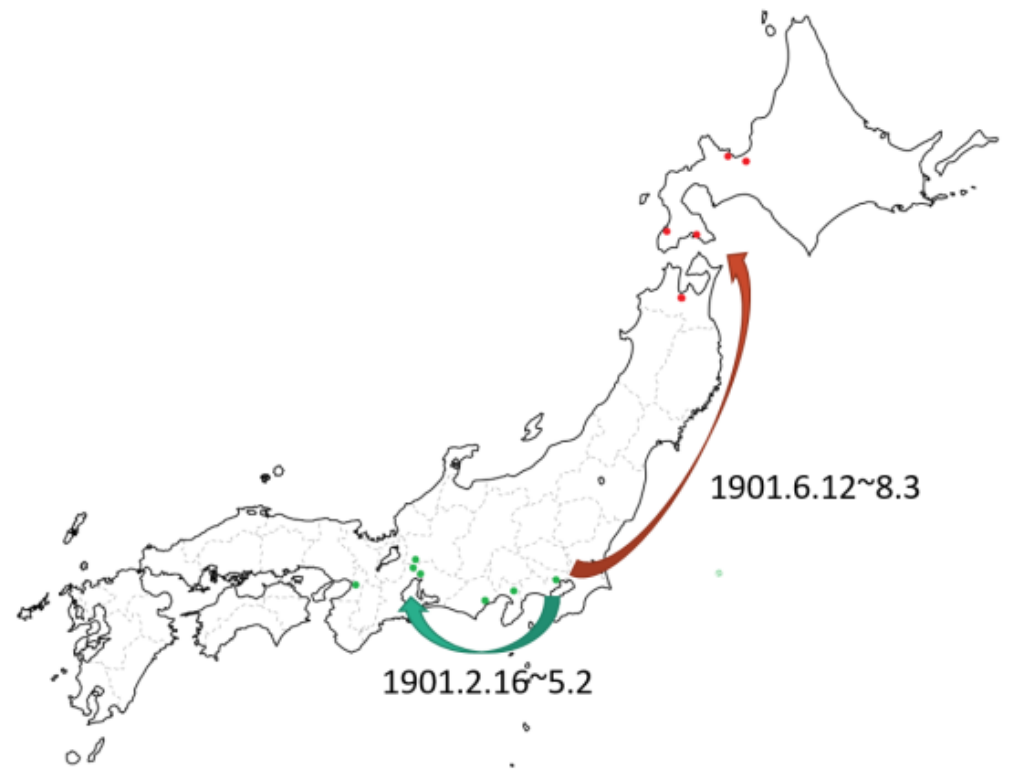

36 Fukagawa Junichi's address recorded in Chiurok is Seki, Gifu.

37 "Yamamoto-ssi puin chŭk Fukagawa-kun maeya" (Yamamoto's wife, in other words, Fukagawa's younger sister), Pukyu ilgi, 3-4. 
gests that $\mathrm{Yu}$ probably met these people on his trip to Hokkaido. Among those involved in the coup, Katono Ritsu (上遠野栗) is from Akita, the hometown of Izaka Shinkan, who sent a letter to $\mathrm{Yu}$ and also met him in person. Tsunematsu Ryukei (恒松隆慶, Add 1-1) published Hokkaido shisatsudan(Stories of visits to Hokkaido)in 1897. And although Yu did not meet him on this trip, Karo Takejiro (加藤武次郎, Add 1-54) is presumed to be related to Kato Takejiro and Kato Takeie.

\section{Banishment to the Ogasawara Islands and Return to Tokyo}

After the coup d'état failed, Yu Kilchun was banished to the Ogasawara Islands. Yu's letters at this time were all censored, and there are some records of senders and recipients. ${ }^{38}$ A comparison of their names on the records and Yu Kilchun's address books reveal the following lists of names:

During his exile on the Ogasawara Islands, only a small number of people stayed in touch with $\mathrm{Yu}$ Kilchun, considering his broad personal ties and connections. And information on most of the people who remained in touch with $\mathrm{Yu}$ is difficult to find. There are possibilities of Koreans using Japanese names or aliases, or contacting $\mathrm{Yu}$ through their acquaintances rather than directly contacting him. ${ }^{39}$ However, it is impossible to further explore and examine these possibilities.

38 Yosich'al Han'gukin kŏdong (Activities of people under surveillance) 3, Kuksa Py'ŏnch'an Wiwŏnhoe, May 5, 1904, "Kanjin no dosei” (Movements of Koreans), 41-42; July 30, 1904, "Yu Kilchun ŭi sŏsin palsusinja myŏngdan" (List of people who sent or received letters from Yu Kilchun), 64; April 12, 1905 "Hanin tongjŏng" (Korean nationals' movements), 97-98; July 26, 1905, "Kanjin no shutsunyu ni tuki" (Entry and exit of Koreans), 116; November 28, 1905, "Kanjin no raio" (Korean people's correspondences), 132-133.

39 Address book 1 contains names of Koreans who saught asylum in Japan. Among them, some Koreans are listed under their Japanese names: Cho Chungŭng = Yoshimi Jintatsu and Yuk Chongyun=Narita Nobuo. 
Table 4. Yu Kilchun's Address Books Reveal the Following Lists of Names

\begin{tabular}{|c|c|}
\hline $\begin{array}{l}\text { People whose } \\
\text { names are } \\
\text { found in the } \\
\text { address books }\end{array}$ & $\begin{array}{l}\text { Kim Yŏngchin (金英鎭, Add 1-138; Chi-245; - Chi-300; Chi- } \\
\text { 587), Kondo Keijo (近藤圭三, Add 1-20), Yoshimura Yoshi- } \\
\text { chi (吉村要質, Add 1-62), Katono Ritsu (上遠野栗, Add 1-23; } \\
\text { Chi-114; Chi-572), Sang Ho (尚影, Add 1-136), Shinohara } \\
\text { Ryokai (葆原亮海, Add 1-53; Chi-562), Sudo Konjo } \\
\text { (須藤今三, Chi-152), Sudo Genjiro (須藤源次郎, Add 1-19), } \\
\text { Suzuki Jojo (鈴木錠藏, Add 1-27; Add 1-123; Chi-84; Chi- } \\
\text { 578), Chang Pak (張博, Chi-3) Yuk Chongyun (陸鍾允, (Nari- } \\
\text { ta Nobuo, 成田信雄), Add 1-142; Chi-523), Cho Chungung } \\
\text { (趙重應, [Yoshimi Jintatsu, 吉見仁達], Add 1-131; Chi-13; } \\
\text { Chi-443), Shimura Jiro (志村次郎, or Shimura Fumijiro } \\
\text { [志村文次郎], Chi-558), Asanuma Sadaichi (淺沼禎一, Chi- } \\
\text { 147; Chi-272), Arai Tokuichi (荒井德一, Add 1-115) }\end{array}$ \\
\hline $\begin{array}{l}\text { People whose } \\
\text { names are not } \\
\text { found in the } \\
\text { address books }\end{array}$ & $\begin{array}{l}\text { Takashima Yubi (高島指), Kudo Iwamatsu (工藤岩松), Kiku- } \\
\text { chi Yamazaburo (菊地山三郎), Omura Tomozo (大村智三), } \\
\text { Oyama Tadaaki (大山忠章), Oyama Ansho (大山安正), } \\
\text { Tamaki Ryukichi (玉木留吉), Uno Yoshitaro (宇野義太郎), Yi } \\
\text { Sŏnjae (李嫧在), Kawashima Sadajiro (川島定次郎), Shimizu } \\
\text { Yoshimoto (淸水義質) }\end{array}$ \\
\hline
\end{tabular}

During his exile, $\mathrm{Yu}$ Kilchun stayed on the Ogasawara Islands for about four years, from May 1902 to March 1906. It seems that he interacted and communicated with the residents of the islands, as contact information for Azaka Taichiro (阿坂多一郎, Add 1-37), Ari Kotaro (阿利孝 太郎, Add 1-38), and Samejima Seijun (鮫島正純, Chi-145; Chi-553), who were residents of the islands, can be found in his address book. Moreover, when Yu passed away, Amenomori Testunojo (雨森鐵之丞) and Okumura Shigeru (奧村茂), who were from Hachijo-jima, an island located north of the Osagawara Islands, sent condolence letters to Yu's family. ${ }^{40}$

Yu left the Ogasawara Islands and arrived in Tokyo on March 21, 1906, and stayed at Cho Hŭiyŏn's house. ${ }^{41}$ Afterwards, Yu worked with Cho

40 Chojang(吊狀, Condolence letters), Collection of new materials related to Yu Kilchun.

41 "Kankoku bomeisha ni tsuite" (Korean exiles), March 24, 1906, Yosich'al Han'gukin kŏdong (Activities of people under surveillance) 3, 141. 
Hŭiyŏn in most matters. A year later, on March 7, 1907, an excerpt from an unfinished manuscript of Yu Kilchun's "Chŏngch'ihak" (Political studies) was published in Mansebo (Independence News). ${ }^{42}$ None of the previous studies explored the background to the publication of "Chŏngch'ihak" in Mansebo.

The process of the publication of "Chŏngch'ihak" in Mansebo can be explained by Yu's relationship with the people involved with Tonga Ch'ŏngnyŏnhoe (East Asian Youth Association) and Irhan Tongjihoe (Japan-Korea Friendship Society). ${ }^{43}$ Tonga Ch'ŏngnyŏnhoe was founded in Tokyo on September 10, 1904, and the founding organizers are as follows:

Nakamura Tahachiro (中村太八郎, Add 1-9; Chi-566), Ishikawa Yasujiro (石川安次郎, Chi-112; Chi-593), Yamaji Yakichi (山路彌吉, or Yamaji Aizan [山路愛山], Add 1-67), Higuchi Hideo (樋口秀雄, Chi-107), Maruyama Nagato (丸山長渡), Hokaku Zenkyo (寶閣善敎), Kato Masaharu (加藤正治), Takimura Ayao (瀧村斐男), Kutsumi Yasutada (久津見息忠), Anezaki Seiji (姊崎政治), Chinese: Fan Yuanlian (范源廉), Lu Shifen (陸世芬), Wang Rongshu (王榮樹), Yang Du (楊度), Li Yuan (黎淵)

42 For the analysis of "Chŏngch'ihak,"refer to Yun, "Yu Kilchun ŭi iphŏn kunjujeron: mijŏnggo 'Chŏngch'ihak' ŭl chungsim ŭro" (Yu Kilchun's theory of constitutional monarchy: focusing on the unpublished manuscript of "Chŏngch'ihak"), Yu Kilchun yŏn'gu.

43 The members of Tonga Ch'ŏngnyŏnhoe and Irhan Tongjihoe were almost the same. For an overview of the members of the organizations, this study referred to Ikegawa Hidekatsu, 1990, "Nikkan Doshikaini tsuite" (On Irhan Tongjihoe). Chosen gakuho (Journal of the Academic Association of Koreanology in Japan) 135. All information about the two organizations mentioned hereafter are from the above source and will not be individually footnoted. Also, as Japanese nationals were main agents of the organization, "Ilhan Tongjihoe" will be referred to as "Ilhan Tongjihoe" (Japan-Korea Friendship Society) instead of "Hanil Tongjihoe" (Korea-Japan Friendship Society). 
The names of main founding organizers, Nakamura Tahachiro, Ishikawa Yasujiro, Yamaji Aizan, and Higuchi Hideo, can be found in Yu Kilchun's address books. Besides the names mentioned above, Nakamura Miroku (中村彌六, Add 1-57; Add 1-110), Ueno Yasutaro (上埜安太郎, Add 1-12), Kanazawa Shozaburo (金澤庄三郎, Add 1-14; Chi-564), and Kaji Jueikichi (加治壽衛吉, Add 1-60) from Yu's address books were also members of Tonga Ch'ŏngnyŏnhoe and Irhan Tongjihoe. ${ }^{44}$

The first time Korean nationals participated in Tonga Ch'ŏngnyŏnhoe was at the fifth social gathering of the association on January 15, 1905. The names of the participants are unknown. Yi Inchik (李仁稙), Cho Minhŭi (趙民熙) who was the Korean minister to Japan, and interpreter Pak Yŏngsun (朴永純) attended the association's regular meeting on March 5, 1905, and Cho Chungŭng and other Korean students who were studying abroad in Japan attended the welcoming reception for Ishikawa Yasujiro upon his return to Japan on March 5, 1906. Yu Kilchun also attended the spring convention held in 1907. According to Ishikawa's journal, Ishikawa and Nakamura Tahachiro met with Pak Yŏnghyo and Yu Kilchun at Kairakuen. ${ }^{45}$ Although Yu Kilchun's participation in Irhan Tongjihoe has not been confirmed, the Japanese nationals with whom Yu Kilchun often contacted and interacted with were members of the society. ${ }^{46}$

Nakamura Tahachiro was a close friend of Tarui Tokichi (樽井藤吉). ${ }^{47}$ Tarui's name (Add 1-108) can be found in one of Yu's address books because Yu became acquainted with him through Nakamura.

44 Hirano, Yoshitaro. 1938. Fusen, tochi kokuyuron no chichi Nakamura Tahachiro den (The father of general election and the theory of land nationalization: A biography of Nakamura Tahachiro), Nakamura Mari, 81-82, 84.

45 Ikegawa, "Nikkan Doshikaini," Chosen gakuho 135, 107.

46 Yu's activities after his return to Korea in 1907 will be addressed in a separate study. Information about Yu's activities after his return in 1907 will not be mentioned in detail from here on.

47 Tanaka Sogoro, 1930, Tōyō Shakaitō kō (Ideas of the Oriental Socialist Party), Ichigen-sha, 3. 
One name of interest in Tonga Ch'ŏngnyŏnhoe and Irhan Tongjihoe is Yi Inchik (李人稙), whose participation in the association and the society began on March 5, 1905. His name does not appear in Yu's address books. $\mathrm{Yu}$ never became acquainted with him since Yi returned to Korea and was working as the editor in chief of Kungmin Sinbo by February 1906. Then in June of the same year, he had become the editor in chief of Mansebo. The first issue of Mansebo was published by Son Pyŏnghŭi (孫 秉熙, Chi-533), the leader of Tonghak (Eastern Learning), and the chair of Mansebo was O Sech'ang (吳世昌, Add 1-139; Chi-20; Chi-485), who had joined Yu Kilchun in the Hyŏngmyŏng Ilsimhoe incident.

Yu Kilchun's relationship with Tonghak can be confirmed in Address book 2. Most of the students studying in Japan, whose names were recorded in this address book, had participated in the Tanji Tongmaeng (Finger Cutting League). ${ }^{48}$ The Tanji Tongmaeng was formed in January 1907 by a group of Korean students studying in Japan who sliced off their fingers in protest against the Japan-Korea Treaty of 1905. The list of students who participated in the league is as follows:

Participants in Tanji Tongmaeng from Address book 2 (20 out of 36) Kim Yunyŏng (金潤英, Add 2-33; Chi-248; Chi-355), Kim Ch'angha (金昌河, Add 2-31), Kim Ch'iryŏn (金致鍊, Add 2-25), Min Chaehyŏn (閔在賢, Add 2-12), Pak Yunchŏl (朴允喆, Add 2-20), Paek Chonghyŏp (白宗冾, Add 2-28), Sǒ Yunkyŏng (徐允京, Add 226), An Hŭisŏ (安希貞, Add 2-29), Yang Taekyŏng (梁大卿, Add 219), Yu Yŏnghŭi (劉永熙, Chi-88;Add 2-15; Add 2-434), Yi Sŏnkyŏng (李善暻, Add 2-18), Yi Yunch'an (李允燦, Add 2-24), Yi Hŭich’ŏl (李熙澈, Add 2-34; Chi-193), Chang Kyŏngrak (張景洛,

48 This study referred to Yi Yongch'ang, 2011, "Tonghak (hapdong) iljinhoe ŭi Ilbon yuhaksaeng p'agyŏn kwa Tanji tongmaeng" (The students sent by the Tonghak Order and Iljinhoe to study abroad and Finger Cutting League), Tonghak Hakbo 22, to confirm the students sent by the Tonghak Order to study in Japan as well as the members of Tanji Tongmaeng. 
Add 2-23), Chang Unryong (張雲龍, Add 2-16), Chŏng It’ae (鄭利泰, Add 2-27), Ch’oe Ch'ungho (崔忠昊, Add 2-22), Han Munsŏn (韓文 善, Add 2-21), Han Munŏn (韓文彦, Add 2-30), Ham Chunho (咸俊 影, Add 2-32)

All of the students who had been sent to Japan through the Tonghak Order have not yet been accounted for, but it seems that there were students sent by the Tonghak Order who did not participate in Tanji Tongmaeng. As mentioned earlier, Yu's Address book 2 contained 36 names, of which 20 were students from the Tonghak Order. There is no information on the other 16 names. Although evidences of Yu's communication or contact with Son Pyŏnghŭi the leader of Tonghak, have not been found, ${ }^{49}$ Yu's relationship with Yi Inchik, O Sech'ang, and the students sent to Japan through the Tonghak Order suggest that $\mathrm{Yu}$ had a point of contact with Tonghak.

The issue of Mansebo published on July 7, 1906, includes an editorial in classical Chinese by Ishikawa. ${ }^{50}$ Then another article titled "A copy of Tonga Ch'ŏngnyŏnhoe Newsletter: Cosmopolitanism and Nationalism (Chinese, Yang Du)” (東亞靑年會報謄世界主義與國家主義 [清國人楊度]) was published. ${ }^{51}$ These articles were a result of the relationship among Yi Inchik, Tonga Ch'ŏngnyŏnhoe, and Irhan Tongjihoe. It can be speculated that Yu Kilchun's "Chŏngch'ihak" was also published in Mansebo through his ties to Yi Inchik and O Sech'ang. There are a number of long pieces of writing in Mansebo, and we cannot completely rule out the fact that one or a few of them might have been written by Yu Kilchun.

Address book 1, the address book that Yu kept before his exile, contains a considerable number of names that have not been mentioned in this paper. It is noteworthy that people who reside in Nagano (長野縣), ${ }^{52}$

49 Son Pyŏnghŭi used an alias, "Yi Sanghŏn," during his exile, but it is possible that he had other aliases recorded in Yu's address books.

50 Mansebo, July 7, 1906, 1.

51 Mansebo, July 12, 1906, 1. 
Yamanashi. (山梨縣), ${ }^{53}$ Fukui (福井縣), ${ }^{54}$ and Toyama (富山縣) ${ }^{55}$ are recorded together. Just from the address books, it seems that after Yu left the Ogasawara Islands and arrived in Tokyo, he traveled to the northern Chubu region of Japan. Although the specific details of his travels are unknown, there are documents that show the purpose of Yu's trip, such as a contract for the sales of medicine (Collection of new materials) between $\mathrm{Yu}$ and Hinata Uhachiro (日南田宇八郎, Add 1-100), the manager of Toyama Baiyaku Dogyokumiai (富山賣藥同業組合, Toyama Pharmaceutical Trade Association), signed on December 3, 1906.

Figure 5. Yanjŏngsŏ (Contract, December 3, 1906)
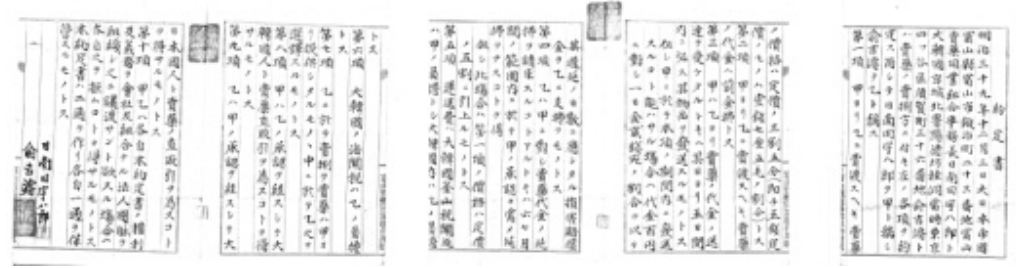

According to this contract, $\mathrm{Yu}$ was to purchase medicines from Hinata at 35 percent of the fixed price to sell them in Korea. It is unclear whether

52 Tahara Hidehito (田原秀人, Add 1-68), Asakawa Korekatsu (淺川是勝, Add 1-69), Yumoto Anun (湯本安運, Add 1-70), Ide Tojiro (井出登一郎, Add 1-71), Nitta Shinzaburo (新田新三郎, Add 1-73), Kanayama Kaemyoshi (金山龜儀, Add 1-76), Tanaka Toshisato (田中敏理, Add 1-77), Uchimura Hisuke (內村日助, Add 1-79).

53 Shinohara Nobuyasu (篠原信康, Add 1-80), Muramatsu Shiko (村松志孝, Add 181), Tsuchiya Kiichiro (土屋喜一郎, Add 1-82), Kono Toyosa (河野豊佐, Add 183), Ono Yukei (小野由馨, Add 1-84), Muramatsu Shiko (村松甚藏, Add 1-85).

54 Yamashina Sharoku (山品捨錄, Add 1-89), Tsuchiu Akira (土生彰, Add 1-90), Togo Tatsuo (東㰾龍雄, Add 1-91), Kuroda Ijuro (黑田懿十郎, Add 1-92), Tsukahara Yoshisaburo (塚原儀三郎, Add 1-93), Tsujioka Taku (辻岡卓. Add 1-94), Ishida Rai (石田否, Add 1-95), Koyama Kyosho (狛呚澄, Add 1-96), Okubo Toshiji (大九保鋑爾, Add 1-97), Takeo Shigeru (竹尾茂, Add 1-98), Shinohara Tatsuji (篠原龍治, Add 1-99).

55 Hiata Uhachiro (日南田宇八郎, Add 1-100). 
$\mathrm{Yu}$ Kilchun actually engaged in medicine sales in Korea. Also it is important to note that December 1906 was a time when the possibility of his return to Korea was uncertain. As examined in the previous chapters, $\mathrm{Yu}$ was able to express his opinions through the Korean press with the help of O Sech'ang and others. In the same way, it seems that Yu attempted to take part in trade through his ties to the members of the Japan-Korea Friendship Society.

These points to the possibility that $\mathrm{Yu}$ traveled through the northern Chubu region for the promotion of industries. Among the residents of Fukui, Yamashima Sharoku (山品捨錄) was the mayor of Fukui City; Kuroda Ijuro (黑田懿十郎) was the director of the Security Division of Fukui; Tsukahara Yoshisaburo (塚原儀三郎) was the deputy mayor of Fukui City; Tsujioka Taku (过岡卓) was the chair of the city council; and Ishida Rai (石田否) was the president of Kyu Ni Bank (九二銀行). Assuming from the positions these people were in, Yu Kilchun seems to have been

Figure 6. Yanjŏngsŏ (Contract, December 3, 1906)

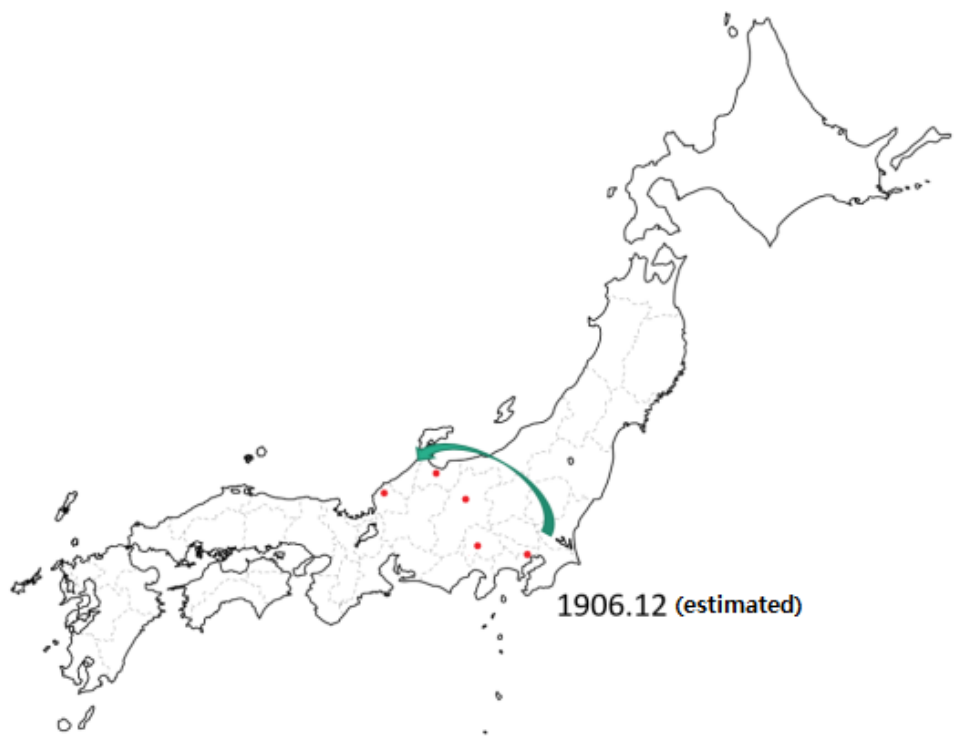


meeting with politicians and men of influence for some kind of movement. Meanwhile, there were no people of political influence among those $\mathrm{Yu}$ met in Nagano and Yamanashi. Nakamura Tahachiro, an important member of the Japan-Korea Friendship Association, was from Nagano, and he had been planning on transplanting crops and sericulture from Nagano to Korea through Yu Kilchun after Japan's annexation of Korea. ${ }^{56}$ The residents of Nagano and Yamanashi in the address books are speculated to have been powerful men in commerce, industry, and agriculture sectors in those regions.

\section{Conclusion}

It is difficult to find previous studies that make use of Yu's address books. While these address books are valuable sources that provide a glimpse into the private sphere of one person's life, research methodologies that maximize the use of such materials have not been developed yet. In Yu Kilchun's case, newspaper articles, reports from the government authorities, and journals included in the Collection of new materials provided information that shed light on the relationship between Yu Kilchun and the people listed in the address books.

The content of this paper can be summarized as follows:

From the time of his studies in Japan until his return to Korea in 1907, Yu Kilchun's acquaintances can be divided into three categories: people Yu met during his studies at Keio Gijuku, people Yu met to plan a coup during his exile, and people who participated in Tonga Ch’ŏngnyŏnhoe and Irhan Tongjihoe from 1906. Although his time at Keio Gijuku was not long, the people he met during his studies formed a strong bond, and a network of academic contacts was established through reunions. These

56 For instance, the letter Nakamura Tahachiro sent to Yu Kilchun on September 4, 1911. Letters, included in the Collection of new materials related to Yu Kilchun, will be organized and analyzed in a different paper. 
connections played a crucial role when $\mathrm{Yu}$ was active in the political scene in 1894 during the Kabo Reform period. After Yu left Korea on exile following Emperor Kojong's flight to the Russian legation in February 1896, he established a new network of acquaintances. Specifically, his journals from 1901 reveal that Yu was searching for people in Shizuoka, Gifu, and Hokkaido, who would take part in his conspiracy. Since he came to Tokyo after serving his time at the Ogasawara Islands, he worked with Tonga Ch'ŏngnyŏnhoe and Irhan Tongjihoe. Additionally, this paper demonstrates that he had connections with the Tonghak Order, and that it was possible for $\mathrm{Yu}$ to express his opinions in the press through $\mathrm{O} \mathrm{Se}-$ ch'ang and Yi Inchik, who were residing in Korea. Around the same time, he also traveled around Yamanashi, Nagano, Toyama, and Fukui, and made efforts to facilitate trade between Korea and Japan. Such efforts were feasible thanks to the network of supporters in Korea.

Moreover, this study proposes a new perspective that information on even the people who have been difficult to identify due to the lack of resources can partly be deduced by analyzing the nature of the address books. Since the address books are deemed to have been created after 1906, it is difficult to ascertain Yu's network of acquaintances from before his exile in 1895. Due to these limitations of sources, most of Yu's acquaintances explored and revealed in this paper are Japanese.

A network of acquaintances can be considered the foundation of one's social activities. It can be a crucial factor in restricting one's actions and activities, which also can be explained by the people in his network. As this paper focused on checking the facts, Yu's network of acquaintances was not sufficiently explored to discuss how it might have restricted his actions or was relevant to his activities. Regarding this topic, I would like to conduct further research and analyze Yu Kilchun's network of acquaintances that was formed after his return from exile in 1907. 


\section{References}

1. Chiurok (Records of close acquaintances, Collection of new materials related to $\mathrm{Yu}$ Kilchun)

2. Address book1 (Chusorok1, Collection of new materials related to Yu Kilchun)

3. Address book2 (Chusorok2, Collection of new materials related to $\mathrm{Yu}$ Kilchun)

4. Haengsaek (Collection of new materials related to Yu Kilchun)

5. Pukyu ilgi (or Pukhaenggi, Collection of new materials related to $\mathrm{Yu}$ Kilchun)

6. Yakjŏngsŏ (Contract, Collection of new materials related to $\mathrm{Yu}$ Kilchun)

7. Chojang (Condolence letters, Collection of new materials related to $\mathrm{Yu}$ Kilchun)

8. Yu Kilchun chŏnsŏ (Collected works of Yu Kilchun)

9. Sokŭmch'ŏngsa (Sequel to the history of my days) Vol. 1, Kuksa Py’ŏnch'an Wiwŏnhoe.

10. Mansebo

11. Nippon Gaiko Bunsho (Documents of Japanese foreign policy) 29.

12. Yosich'al Han'gukin kŏdong (Activities of people under surveillance) 2 and 3, Kuksa Py'ŏnch'an Wiwŏnhoe.

13. Ito Hirobumi kankei monjo (Documents related to Ito History) 6 and 7.

14. Yomiuri Shimbun

15. Jiji Shinpo

16. Yu, Tongchun. 1987. Yu Kilchun chŏn (A biography of Yu Kilchun). Iljogak.

17. Yu, Yŏngik. 1990. Kabo kyŏngjang yŏn'gu (A study on the Kabo Reforms). Iljogak.

18. Yi, Kwangnin. 1991. Yu Kilchun: tach'in sahoe e tŏnjin ch'unggyŏk (Yu Kilchun: a shock through a closed society). Tonga Ilbosa.

19. An, Yongsik. 1994. Han'guk haengjŏngsa yŏn'gu (A study of the 
history of Korean administration) Vol. 1. Taeyŏng Munhwasa.

20. Chŏn, Pokhŭi. 1996. Sahoe chinhwaron kwa kukga sasang (The theory of social evolution and national ideologies). Hanul.

21. Yun, Pyŏnghŭi. 1998. Yu Kilchun yŏn'gu (A study on Yu Kilchun). Kukhak Charyowŏn.

22. Hŏ, Tonghyŏn. 2002. "1880 nyŏndae kaehwap'a insadŭl ŭi sahoe chinhwaron suyong yangt'ae pigyo yŏn'gu" (A comparative study of the attitude of acceptance of the theory of social evolution by the members of the Enlightenment Party). Sach'ong (The historical journal) 55 .

23. Wang, Hyŏnjong. 2003. Han'guk kŭndae kukga ŭi hyŏngsŏng kwa Kabo kaehyŏk (The formation of modern nation of Korea and the Kabo Reforms). Yŏksa Pip'yŏngsa.

24. Chŏng, Yonghwa. 2004. Munmyŏng ŭi chŏngch î sasang: Yu Kilchun gwa kŭndae Han'guk (Political ideologies of civilization: Yu Kilchun and modern Korea). Munhakgwa Chisŏngsa.

25. Han, Ch'ŏlho. 2009. Han'guk kündae kaehwap'a wa t'ongch'i kigu yŏn'gu (A study of the Enlightenment Party and the governing body in modern Korea). Sŏnin.

26. Yi, Yongch'ang. 2011. "Tonghak kyodan kwa (hapdong) iljinhoe ŭi Ilbon yuhaksaeng p'agyŏn kwa Tanji tongmaeng” (The students sent by the Tonghak Order and Iljinhoe to study abroad and Finger Cutting League). Tonghak Hakbo 22.

27. Ch'oe, Tŏksu. 2015. 'Haebang hu Yu Kilchun yŏn'gu ŭi sŏnggwa wa kwaje" (Achievements and problems of the research on Yu Kilchun since the Korean liberation from the Japanese rule). Ch'oe Tŏksu p'yŏn. Kündae Han'guk ŭi kaehyŏk kusang kwa Yu Kilchun (Reform ideas in modern Korea and $\mathrm{Yu}$ Kilchun). Koryŏ Taehakkyo Ch'ulp'an Munhwawŏn.

28. Tanaka, Sogoro. 1930.Tōyō Shakaitō kō (Ideas of the Oriental Socialist Party). Ichigen-sha.

29. Hirano, Yoshitaro. 1938. Fusen, tochi kokuyuron no chichi Nakamura Tahachiro den (The father of general election and the theory of 
land nationalization: A biography of Nakamur'a Tahachiro). Nakamura Mari.

30. Ikegawa, Hidekatsu. 1990. "Nikkan Doshikaini tsuite" (On Irhan Tongjihoe). Chosen gakuho (Journal of the Academic Association of Koreanology in Japan) 135.

31. Keio Gijuku, ed. 2001. Fukuzawa Yukichi shokanshu (Collection of Fukuzawa Yukichi's letters) 3 and 4. Iwanami Shoten.

32. Tsukiashi, Tatsuhiko. 2009. Chosen kaika shiso to nashonarizumu (Enlightenment thought and nationalism in Korea). Tokyo Daigaku Shuppankai. 
$<$ Abstract $>$

\section{A Study on Yu Kilchun and His Network of Acquaintances (1881-1907)}

Masutani Yuichi

From the time of his studies in Japan until his return to Korea in 1907, Yu Kilchun's acquaintances can be divided into three categories: people Yu met during his studies at Keio Gijuku, people Yu met to plan a coup during his exile, and people who participated in Tonga Ch'ŏngnyŏnhoe and Irhan Tongjihoe from 1906.Although his time at Keio Gijuku was not long, the people he met during his studies bonded strongly, and a network of academic contacts was formed through reunions. These connections played a crucial role when $\mathrm{Yu}$ was active in the political scene in 1894 during the Kabo Reform period. After Yu left Korea on an exile following Emperor Kojong's flight to the Russian legation in February 1896, he established a new network of acquaintances. Specifically, his journals from 1901 revealed that $\mathrm{Yu}$ was searching for people in Shizuoka, Gifu, and Hokkaido, who would take part in his conspiracy. Since he came to Tokyo after serving his time at the Ogasawara Islands, he worked with Tonga Ch'ŏngnyŏnhoe and Irhan Tongjihoe. Additionally, this paper demonstrated that he had connections with the Tonghak Order, and that it was possible for $\mathrm{Yu}$ to express his opinions in the press through O Sech'ang and Yi Inchik, who were residing in Korea. Around the same time, he also traveled around Yamanashi, Nagano, Toyama, and Fukui, and made efforts to facilitate trade between Korea and Japan. Such efforts were feasible thanks to the network of collaborators in Korea.

Keywords: Yu Kilchun, network of acquaintances, school ties, address book, new materials 


\section{<국문초록>}

\section{유길준의 인맥에 대한 연구 (1881-1907)}

마스타니 유이치 (고려대학교 한국사학과 박사과정)

수학 시기부터 1907년 귀국 전까지 유길준의 인맥은 크게 보면, 첫째 수학 시 기 경응의숙에서 형성한 인맥, 둘째 망명 시기 쿠데타 준비를 위하여 구축된 인맥, 셋째 1906년부터 동아청년회, 일한동지회 계열 인사들과의 인맥으로 나눌 수 있 다. 경응의숙에서 수학한 시기는 길지 않았으나, 그 인맥은 두터운 결속력을 가지 고 있었고, 동창회를 통해서 학연이 형성되어 있었다. 1894년 갑오개혁기 유길준 이 정치계에서 활약하였을 때 이 인맥이 크게 작용하였다고 할 수 있다. 1896년 2월 아관파천에 의해서 망명한 후, 유길준은 새롭게 인맥을 구축하였다. 그 구체 적인 움직임으로써 1901년에 쓰인 일기를 통해서 시즈오카, 기후, 홋카이도에서 음모에 가담할 만한 인사를 찾고 있었던 것을 확인하였다. 오가사와라 섬 유배를 거쳐 도쿄로 돌아온 후는 동아청년회, 일한동지회와 행동을 같이하였다. 동시에 동학교단과 관계를 가졌고, 국내에 있는 오세창, 이인직을 통해서 언론에서 의견 을 말할 수 있었던 가능성을 지적하였다. 이 시기 야마나시, 나가노, 도야마, 후쿠 이를 여행하고 한국 내지와 무역 중매를 하려고 기도하였다. 이러한 것이 가능하 였던 것은 국내에 협력자가 있었기 때문이었다.

주제어: 유길준, 인맥, 학연, 주소록, 신자료 
